\title{
Isolation and Identification of Wide-Spectrum Antifungal Bacteria
}

\author{
Omar M. Al-Obaidy \\ Department of Biology \\ College of Science \\ Mosul University
}

(Received 26 / 5 / 2010 ; Accepted 20/9/2010)

\begin{abstract}
A type of bacteria was isolated from garden soils (rhizosphere soils of some garden plants) that showed a great antagonistic activities toward different phytopathogenic and even human and toxin-producing fungi especially Aspergillus spp. Many different tests (Gram stain, shape of cells, shape of colonies, pigment production, swarming on plate, catalase, oxidase, gelatin hydrolysis, indol, growth on salt medium, blood hydrolysis,...) were done for the identification of this bacteria, and the results showed that this bacteria was belonged to the genus of Paenibacillus spp. Also the active antifungal compounds were isolated from this bacteria and many tests were done to partially characterize the nature of the compounds produced by this bacteria.
\end{abstract}

Key words : antagonism, antifungal bacteria.

\section{عزل وتشخيص عزلة بكتيربة مضادة الفاربك ذلتطلف ولسع \\ الملغص}

مُ عزل نوع من البكتريا من مطقة الرايزوسفير rhizosphere لبعض نباتتا الحدائق والتي أظهرت





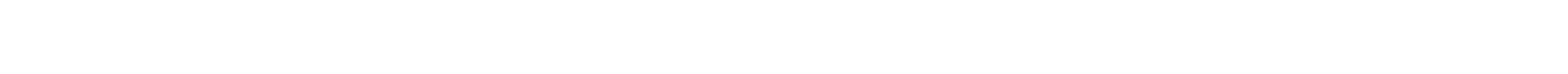

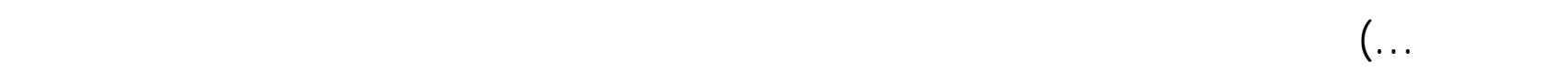


للتعرف جزئيا علىطبيعة هذه المركبت المتتجة من هذه البكتريا. الهاملت الفناحية : التضاد، بكتريا مضادة للنطريك. 


\section{INTRODUCTION}

Fungi are primary causes of grain loss, and some of them produce compounds that are toxic when consumed (Shank, 1974). Fungal diseases of plants are usually controlled by some combination of cultural practices, use of fungicides, and host plant resistance. Fungicides are the primary means of fungal disease control, but their use is currently controversial because investigation have indicated potentially undesirable environmental side effects (Carlile , 1988).

Increased public concern about the accumulation of pesticide residues in the biosphere and the development of resistance among pathogens against conventional antibiotics have led scientists toward the development of alternative strategies for plant disease suppression. Many researchers have unarguably suggested that biological control and use of microbial pesticides are the best alternatives ( Lee et al., 2008). Members of the genus Paenibacillus are common soil bacteria and belong to the group of plant growth-promoting rhizobacteria (PGPR). A range of activities has been found to be associated with Paenibacillus-treatment, some of which might be involved in plant growth promotion (Selim et al., 2005). Indirect promotion of plant growth occurs when PGPR antagonize or prevent the effects of phytopathogens or deleterious microorganisms, and the proposed mechanism for this promotion suggest that the active principle may be a secondary bacterial metabolite which antagonize the pathogens. Many species of the genus Paenibacillus( such as P. polymyxa) are well known to produce antibiotic compounds that suppress several plant pathogens (Lorentz et al., 2006).

The aim of this study is to isolate and identify a Paenibacillus spp. from soil and to test the biological activity of this bacteria against several plant-(and even human-) pathogenic fungi and also to extract and partially characterize the nature of the antifungal compound.

\section{Pathogenic fungal strains}

\section{MATERIALS AND METHODS}

Different pathogenic fungi were used in this study as test fungi, and as follows:

a- Penicillium nalgiovense, Fusarium graminearum, Alternaria alternata , Rhizoctonia solani were taken from Biology Department/College of Science/ Mosul University.

b- Macrophomina phaseolina, was taken from Plant Protection Department/College of Agriculture/ Mosul University.

c- Human pathogenic Aspergillus niger, Trichophyton mentagrophytes and toxin-producing Aspergillus flavus from Biology Department/College of Science/ Mosul University.

\section{Collection of the samples}

Different soil samples (about 12 soil samples) were collected for the isolation of the Gram positive antifungal bacteria and these samples were taken from the rhizosphere soils of different garden plants in Mosul city such as the rhizosphere of flowers and orange trees.

\section{Isolation and identification of bacteria}

Serial dilutions were done for each soil sample (1 gram of the sample is diluted in $9 \mathrm{ml}$ of sterile distilled water, then $1 \mathrm{ml}$ of this dilution is added to another $9 \mathrm{ml}$ of distilled water and the same thing is repeated until we reach the dilution of $10^{-6}$ ), then $0.1 \mathrm{ml}$ of the 
dilutions $10^{-4}$ and $10^{-5}$ of each sample was cultured on $9 \mathrm{~cm}$ Petri dish of nutrient agar and incubated at $30^{\circ} \mathrm{C}$ for 24 hour. After that each different single colonies were tested against pathogenic test fungi, and the antifungal bacterial isolates were taken and recultured for identification and further studies.

The suspected isolates that showed preliminary antifungal activities were subjected to several microscopical tests (shape of cells, shape of spores, swelling of cells), morphological tests (color, size of colonies, edge of colonies, consistency of colonies etc...), biochemical tests (citrate utilization, oxidaze, indol, catalase, gelatin hydrolysis) in addition to the Gram stain, pigment production, swarming on plate, motility test, blood hemolysis, and all of these tests were done according to (Holt et al., 1994; Forbes et al., 2002; Forbes et al., 2007 ; Al-Sammak , 2008).

It was mentioned by a method described by (Al-Sammak , 2008) that in order to differentiate between the Gram positive Bacillus spp. and Paenibacillus spp., the isolates were grown in salt medium (nutrient broth + salt $\mathrm{NaCl}$ ) at concentrations of $3 \%, 5 \%$, and $7 \%$, in which if the isolate is Paenibacillus spp. it will not grow at the salt medium at the concentrations of $5 \%$ and $7 \%$.

\section{Antifungal bioassay test}

In order to examine the antagonistic properties of bacterial isolates against phytopathogenic fungi , and according to (Kobayashi et al., 2000), a dual culture technique was carried out which is the simplest method to detect antifungal activity. In this technique an agar block (5 mm diameter) of 5-day-old culture of fungal pathogen was placed in the centre of plate containing potato dextrose agar (PDA) (or Sabouraud dextrose agar in the case of human pathogenic fungi) according to (Jayaswal et al., 1990). A loopful of 24-h-old culture of the tested bacteria was inoculated at $2 \mathrm{~cm}$ juxtaposed to the pathogen. The fungal pathogen inoculated centrally on PDA (or Sabouraud dextrose agar) plates, and some plates were left without inoculation of the bacteria juxtaposed to the fungal pathogen served as control. The plates were incubated at $28 \pm 1{ }^{\circ} \mathrm{C}$ for 5 days and inhibition of fungal growth was measured (Gupta et al., 2001).

\section{Extraction and partial characterization of the active antifungal compounds}

In order to extract the active antifungal compounds and test its activity against the test fungi and in order to characterize the nature of these compounds, the following method was described :

Nutrient broth (N.B.) medium was inoculated with a loopful of fresh (24-hour old) culture of the bacterial isolate and was incubated at $28 \pm 1{ }^{\circ} \mathrm{C}$ for 5 days. It was then centrifuged at $7000 \mathrm{rpm}$. for $15 \mathrm{~min}$, and the supernatant was finally passed through a millipore filter paper $(0.2 \mu \mathrm{m}$ porosity) to get cell-free culture filtrate that contain the antifungal compound (Gupta et al., 2001).

Several tests were done to partially characterize the nature of the active crude extract such as heat treatment $\left(100^{\circ} \mathrm{C}\right.$ for 3 hours), nature of the compound(s) (protein or not), solubility of the compound (s) in water and organic solvents, FTIR, in which the FTIR analysis was done at the Chemistry Department/College of Education/ Mosul University using FTIR instrument type Bruker-Tensor 27 (Germany) to determine the active groups of the antifungal compound (Seldin et al., 1998 ; Lee et al., 2008). 


\section{Isolation of antifungal bacteria}

\section{RESULTS AND DISCUSSION}

From the twelve soil samples we had about 36 different bacterial isolates of suspected Gram positive bacteria, and each one of these isolates was preliminary tested against the fungus Alternaria alternata (later tested against the other fungi), and we had 4 different bacterial isolates that have an antifungal activities against the test fungi.

\section{Identification of bacterial isolates}

The four bacterial isolates that showed antifungal activities were subjected to several morphological, physiological, and biochemical tests to identify these bacteria, and the results revealed that all the four antifungal isolates belonged to the Gram positive bacteria, and three of these isolates belonged to the genus Bacillus spp., and the other belonged to the genus Paenibacillus spp.

There are many researches concerning the isolation of different antifungal Bacillus isolates such as B.subtilis and B.cereus etc... (Yu et al., 2002 ; Safdi et al., 2002) and according to this (also because the Paenibacillus isolate showed higher inhibition zone on test fungi when compared to other Bacillus isolates) and as we said before we concerned in this research to find an antifungal Paenibacillus spp., therefore the three isolated antifungal Bacillus spp. were neglected and we concerned on antifungal Paenibacillus spp. instead.

The results showed that the antifungal Paenibacillus spp. was unable to grow in the salt medium at the concentrations of $5 \%$ and $7 \%$ and this confirmed that the isolate belong to the Paenibacillus spp., also the tests for the identificatioin of the Paenibacillus spp. showed that the cells are swelled and that the single or discrete colonies are large, circular, convex, smooth, translucent or opaque in color, and the colonies do not produce any pigments(in nutrient agar and broth) and can swarm over agar surface and of mucoid consistency on media containing sugars such as PDA, and of beta- hemolysis on blood agar, and all of these results indicated that the isolate is belonged to the species of Paenibacillus alvei and these results were exactly in agreement with (Forbes et al., 2002; Forbes et al., 2007; AlSammak, 2008).

\section{Antifungal bioassay test}

The Paenibacillus isolate that showed preliminary antifungal activity against the fungus Alternaria alternata, was taken to test its antifungal activity toward several phytopathogenic fungi and even toxin -producing and human pathogenic fungi, and the results are shown in (Table 1), ( See also figures 1,2, and 3) :

Table 1 : The bioeffect of Paenibacillus alvei on different pathogenic fungi.

\begin{tabular}{|c|c|c|}
\hline \multirow{3}{*}{ Bacterial Isolate } & Pathogenic fungi & $\begin{array}{c}\text { Inhibition zone } \\
\text { (mm) }\end{array}$ \\
\hline \multirow{4}{*}{ Paenibacillus alvei } & Alternaria alternata & 7 \\
\cline { 2 - 3 } & Penicillium nalgiovense & 5 \\
\cline { 2 - 3 } & Fusarium graminearum & 5 \\
\cline { 2 - 3 } & Rhizoctonia solani & 5 \\
\cline { 2 - 3 } & Macrophomina phaseolina & 4 \\
\cline { 2 - 3 } & Aspergillus niger & 3 \\
\cline { 2 - 3 } & Aspergillus flavus & 4 \\
\cline { 2 - 3 } & Trichophyton mentagrophytes & 4 \\
\hline
\end{tabular}


It was obvious and from the previous results that the Paenibacillus alvei (which was isolated from the rhizosphere soil of garden flowers) had a wide range of antifungal activities toward a different kinds of pathogenic fungi (phytopathogenic, human-pathogenic, and toxin-producing Aspergillus flavus), thus it could used as a very potent biological control agent toward the mentioned fungi.

In recent years, it was mentioned by many researches that many species of the Gram positive Paenibacillus bacteria (such as Paenibacillus lentimorbus) showed in vitro antagonistic activities against several fungal phytopathogens belonging to the ascomycetes, basidiomycetes, and oomycetes (Lee et al., 2008). The results showed that our Paenibacillus alvei isolate showed or had a wide range of antifungal activities toward many kinds of pathogenic fungi.

There are many different kinds of Gram positive and Gram negative bacteria (such as Bacillus spp. and Pseudomonas spp.) that antagonize or have antifungal activities toward different fungi especially the phytopathogenic fungi (Kobayashi et al., 2000 ; Gupta et al., 2001), but there is a little (if not non) of the researches that showed a bacterial isolate with a wide range of antifungal activities especially toward (for example) the pathogenic Aspergillus spp., thus our antifungal isolate might represent a good alternative or the most potent biological control agent or antifungal isolate even toward the human-pathogenic fungi.

The antifungal activities was due to the production of an extracellular antifungal metabolites or antibiotics that could be extracted for purification or for further studies.

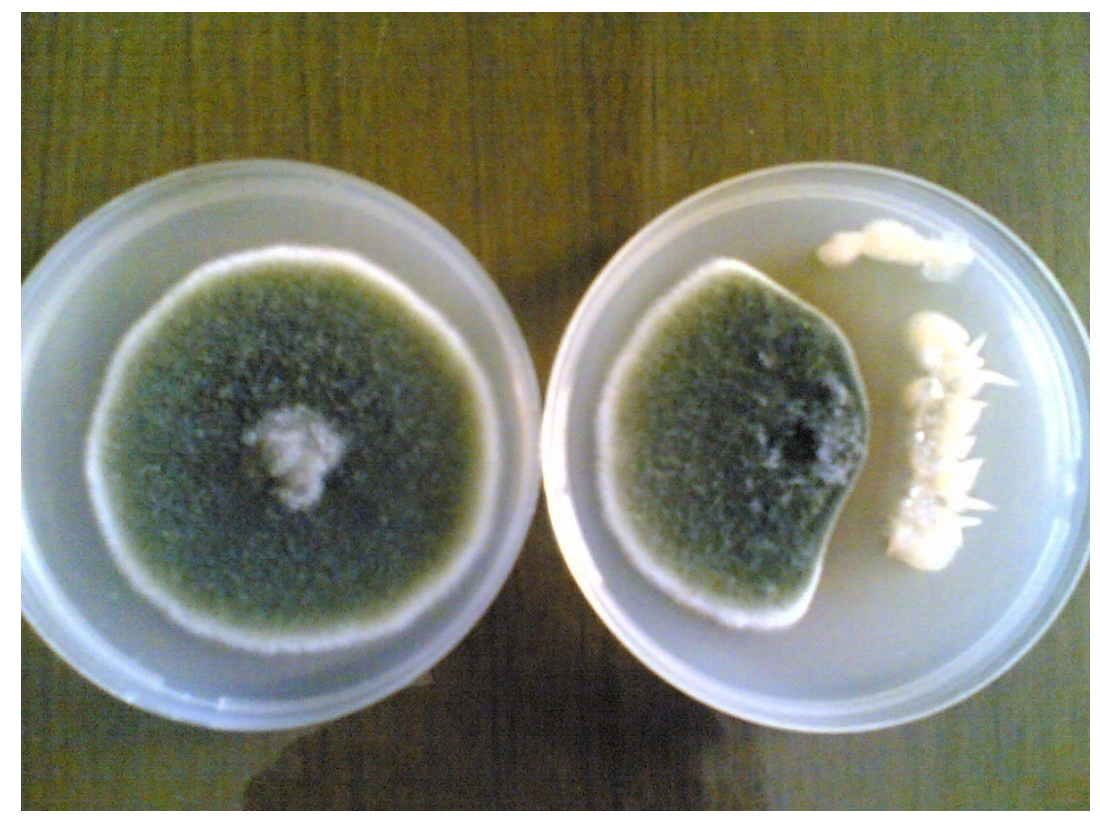

Fig. 1: The biological effect of Paenibacillus alvei (right plate) on phytopathogenic Alternaria alternata (left plate is the fungus control). 


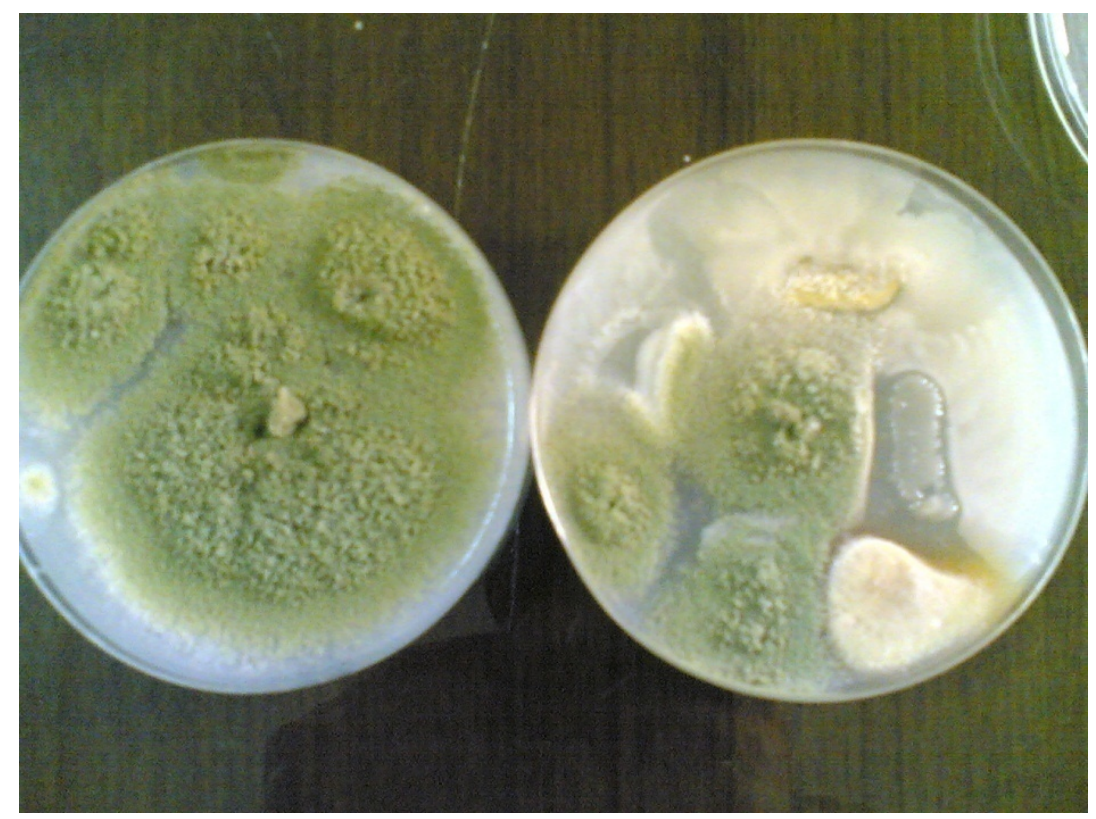

Fig. 2 : The antagonistic activity (inhibition zone) of Paenibacillus alvei (on the right plate) against the toxin-producing Aspergillus flavus (left plate is the fungus control).

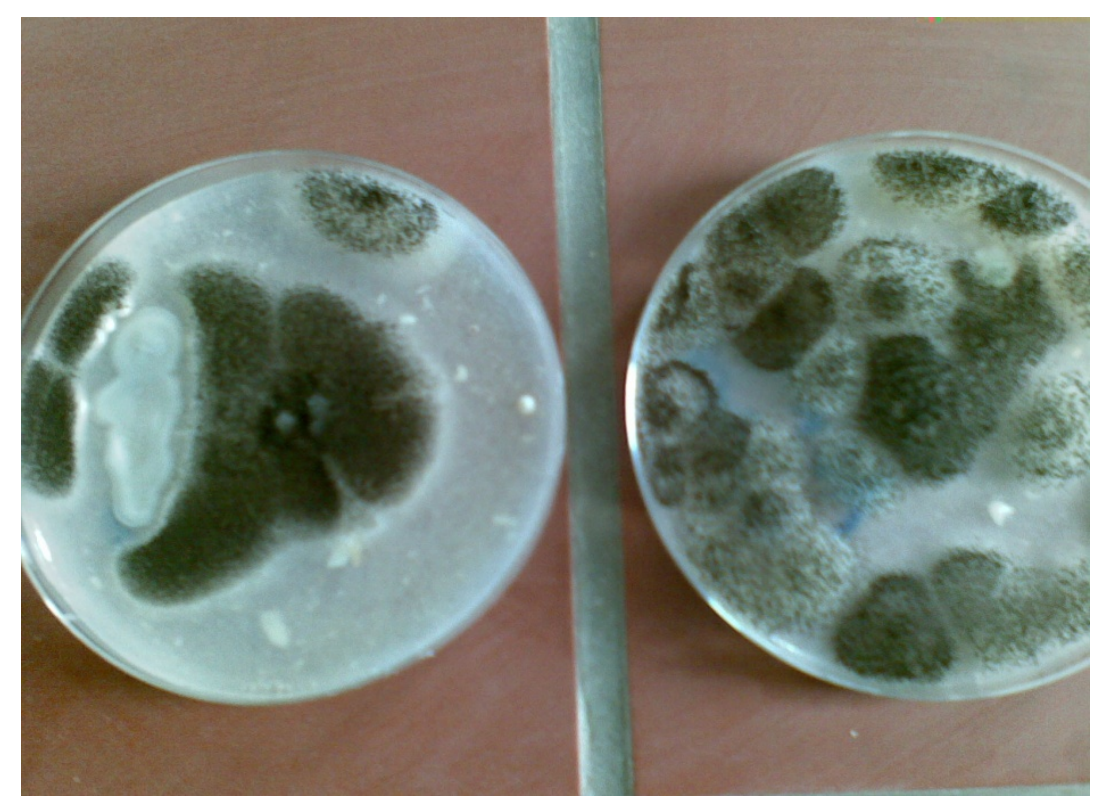

Fig. 3 : The antifungal activity of Paenibacillus isolate (on the left plate) against humanpathogenic Aspergillus niger (right plate is the fungus control).

\section{Extraction and partial characterization of the active antifungal compounds}

A method described by Gupta et al., (2001) was carried out for the extraction of the active antifungal compounds or the culture filtrate from the Paenibacillus alvei, and after 
the extraction and testing it against several pathogenic fungi (Fig. 4), several methods were done to partially characterize the nature of the active compounds and as follow:

The optimum conditions for the production of the compound(s) from Paenibacillus isolate was growing the isolate for 5 days in the culture media (Nutrient Broth) at $28^{\circ} \mathrm{C}$ and that was in agreement with ( Haggag, 2007; Seldin et al., 1998; Beatty and Jensen, 2002).

The culture filtrate of Paenibacillus alvei that contain the active antifungal compound showed different inhibition zones on the test fungi as shown below in (Table 2).

Table 2: The bioeffect of Paenibacillus alvei culture filtrate on different pathogenic fungi.

\begin{tabular}{|l|c|c|}
\hline \multirow{4}{*}{$\begin{array}{l}\text { Culture filtrate effect of } \\
\text { Paenibacillus alvei }\end{array}$} & Test fungi & Inhibition Zone (mm) \\
\cline { 2 - 3 } & Alternaria alternata & 7 \\
\cline { 2 - 3 } & Penicillium nalgiovense & 5 \\
\cline { 2 - 3 } & Fusarium graminearum & 6 \\
\cline { 2 - 3 } & Rhizoctonia solani & 4 \\
\cline { 2 - 3 } & Macrophomina phaseolina & 4 \\
\cline { 2 - 3 } & Trichophyton mentagrophytes & 3 \\
\cline { 2 - 3 } & Aspergillus niger & 4 \\
\cline { 2 - 3 } & Aspergillus flavus & 3 \\
\hline
\end{tabular}

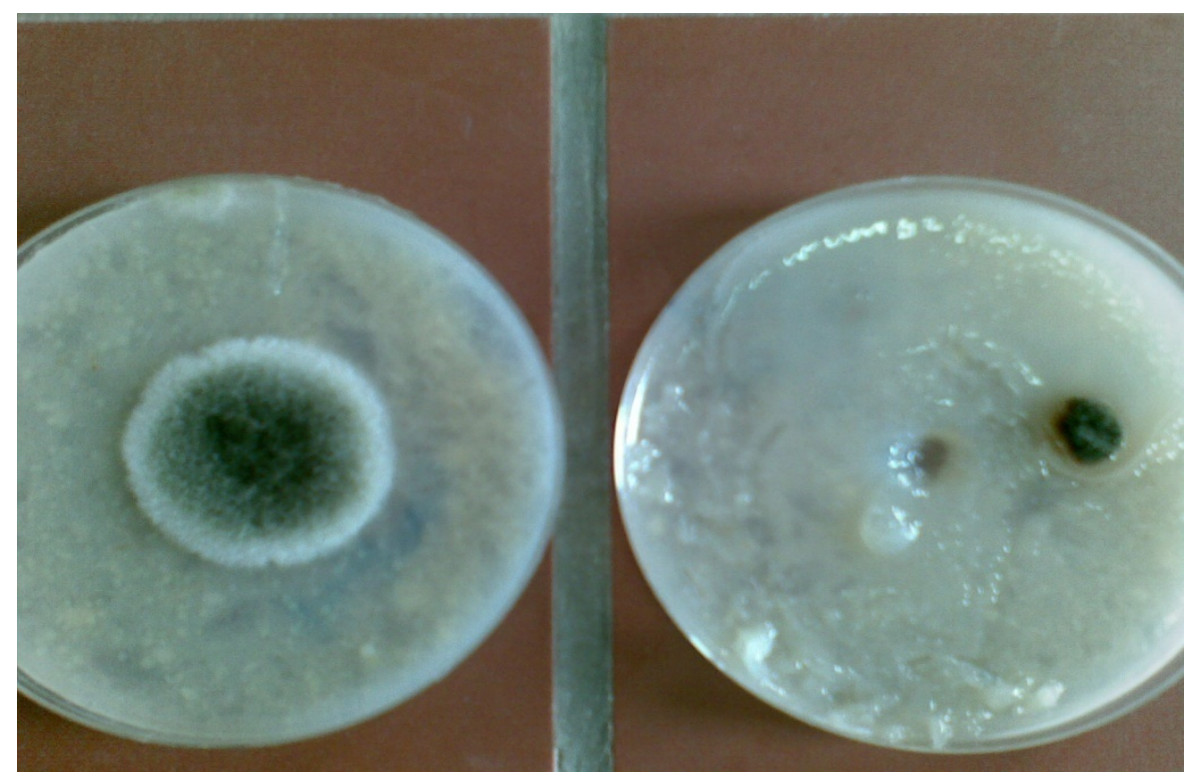

Fig. 4: The biological effect of Paenibacillus culture filtrate (right plate) on the fungus Alternaria alternata compared with control (left plate).

The extracted active compound was soluble in water and organic solvents such as butanol, dimethyl sulfoxide (DMSO), ethanol, acetone and others in which many researches mentioned that the active compounds could be extracted from Paenibacillus spp. with butanol (Lee et al., 2008). 
When a method described by (Seldin et al., 1998 ; Lee et al., 2008) was used to test the heat effect on the active compounds of Paenibacillus spp. in which the crude antifungal metabolites of Paenibacillus spp. was subjected to heat at $100^{\circ} \mathrm{C}$ for 3 hours, it appeared that the active compounds was thermostable in which there was no loss of activity against the test fungi after the heat treatment.

The FTIR analysis of the active antifungal compound (Fig. 5) showed the presence of $\mathrm{C}=\mathrm{N}$ bond at wave number $1632, \mathrm{C}-\mathrm{O}$ bond at $1078, \mathrm{~N}-\mathrm{H}$ or $\mathrm{O}-\mathrm{H}$ bond at wave number 3381, C-H bond at 2969, and aromatic ring at the wave number between 1407 and 1632 .

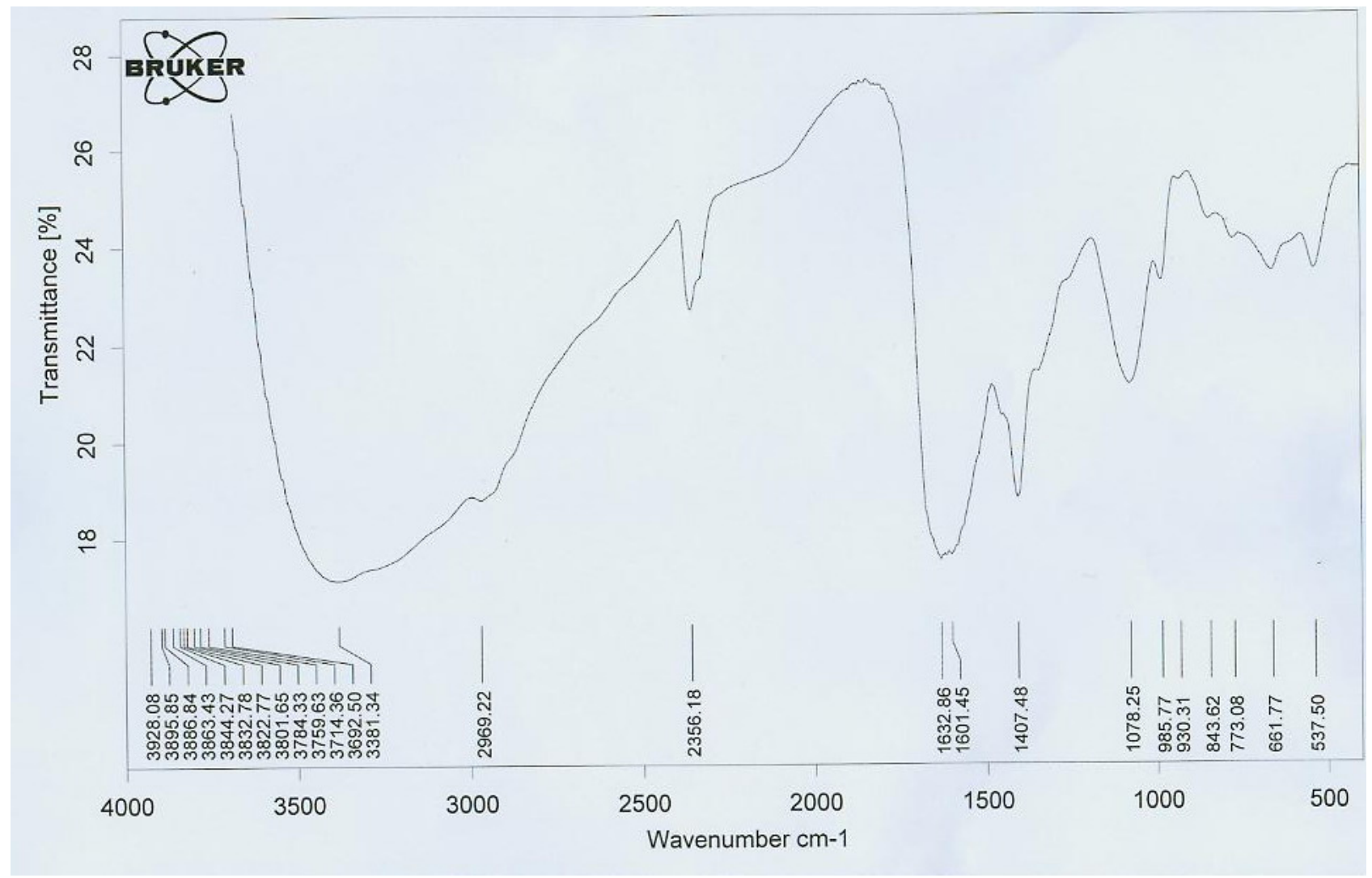

Fig. 5: The FTIR analysis of the active compound of Paenibacillus alvei.

From all above we can conclude that the isolated Gram positive Paenibacillus alvei may represent a potent biological control agent that could be used as a potent alternative to the harmful fungicides with a special property that it had a wide range or spectrum of antifungal properties against different pathogenic fungi and especially against Aspergillus species.

Also it was concluded that the optimum conditions for the production of antifungal compounds from Paenibacillus alvei was growing the bacteria for 5 days in nutrient broth at $28^{\circ} \mathrm{C}$, and that the compound was heat resistant which might be of non-protein in nature and the FTIR analysis showed that the active compound is a complex compound which contain 
an aromatic ring, that is recommended to do a full characterization tests for active compound such as the NMR, mass spectrophotometry, HPLC, and others.

Also it is recommended to test the antagonistic activities of the new Paenibacillus isolate against the other different kinds of human pathogenic fungi, phytopathogenic fungi, and even against the different kinds of Gram positive and Gram negative bacteria.

\section{REFERENCES}

Al-Sammak, E.G. (2008). Numerical classification by cluster analysis of Thermactinomyces species as compared with some species of two genera Bacillus and Paenibacillus.(in Arabic). Al-Rafedain Sci. J. 9(3) , 57-69.

Beatty, P.H.; Jensen, S.E. (2002). Paenibacillus polymyxa produces fusaricidin-type antifungal antibiotics active against Leptosphaeria maculans, the causative agent of blackleg disease of canola. Canadian J. Microb.. 48(2), 159-169.

Carlile, W.R. (1988). "Fungicides". In W.R. Carlile (ed.). Control of Crop Diseases. Edward Arnold Publisher, London. pp. 51-58.

Forbes , B. A. ; Sham, D. F. ; Weissfeld, A. S. (2002). "Bailey and Scott's Diagnostic Microbiology". 11th edn. Mosby Elsevier, St. Louis Missouri. pp. 317-324.

Forbes , B.A. ; Sham, D.F. ; Weissfeld, A.S. (2007). "Bailey and Scott's Diagnostic Microbiology". 12th edn. Mosby Elsevier, St. Louis Missouri. pp. 284-285.

Gupta, C.P.; Dubey, R.C.; Kang, S.C.; Maheshwari, D. K. (2001). Antibiosis-mediated necrotrophic effect of Pseudomonas GRC2 against two fungal plant pathogens. Current Science. 81(1), 91-94.

Haggag, W. M. (2007). Colonization of exopolysaccharide-producing Paenibacillus polymyxa on peanut roots for enhancing resistance against crown rot disease. African J. Biotechn.. 6 (13), 1568-1577.

Holt, J.G.; Krieg, N.R.; Sneath, P. H. A.; Staley, J.T.; Williams, S.T. (1994). "Bergey's Manual of Determinative Bacteriology". Williams and Wilkins Press, London. pp. 93, 94, 151-157.

Jayaswal, R. K.; Fernandez, M. A.; Schroeder, R. G. (1990). Isolation and Characterization of Pseudomonas Strain that Restricts the Growth of Various Phytopathogenic Fungi. Appl. and Environ. Microbiol. 56(4), 1053-1058.

Kobayashi, K.; Laura, G.; Ana, V.; Jorge, yC (2000). Suppressive effects of antagonistic bacteria and metabolites on a pathogenic Rhizoctonia solani strain. Increased production in a specific medium. RIA. 29(2), 63-75.

Lee, Y. K.; Senthilkumar, M. ; Kim, J. H. ; Swarnalakshmi, K. ; Annapurna, K. (2008). Purification and partial characterization of antifungal metabolite from Paenibacillus lentimorbus WJ5. World J. Microbio. and Biotechno. 24 (12), 30573062.

Lorentz, R.H., Artico S., Silveira A.B., Einsfeld A., Corcao G. (2006). Evaluation of antimicrobial activity in Paenibacillus spp. Strains isolated from natural environment. Letters in Appllied Microbiology. 43(5), 541-547.

Safdi, N.; Cherif, M.; Hajlaoui, M. R.; Boudabbous, A.; Belanger, R. (2002). Isolation and partial purification of antifungal metabolites produced by Bacillus cereus. Annual Microbiol., 52, 323-337. 
Seldin, L.; Rosado A.S.; deCruz D.W.; Nobrega A.; VanElsas J.D.; Paiva E. (1998). Comparison of Paenibacillus azotofixans strains isolated from rhizoplane, rhizosphere and non-root-associated soil from maize planted in two different Brazilian soils. Appl. and Environ. Microbiol. 64(10) , 3860-3868.

Selim, S.; Negrel, S.; Goveraets, C.; Gianinazzi, S.; Tuinen, V. (2005). Isolation and partial characterization of antagonistic peptides produced by Paenibacillus sp. Strains B2 isolated from the sorghum mycorrhizosphere. Appl. and Environ. Microbiol. 71(11), 6501-6507.

Shank, R. C. (1974). "Role of Aflatoxin in Human Disease". In Rodricks, J.V. (ed.), Mycotoxins and other fungal related food problems. American Chemical Society, Washington, D.C. pp. 51-58.

Yu, G.Y.; Sinclair, J. B.; Hartman, G. L. ; Bertagnolli, B.L. (2002). Production of iturin A by Bacillus amyloliquefaciens suppressing Rhizoctonia solani. Soil Biol. and Biochem. 34, 955-963. 